
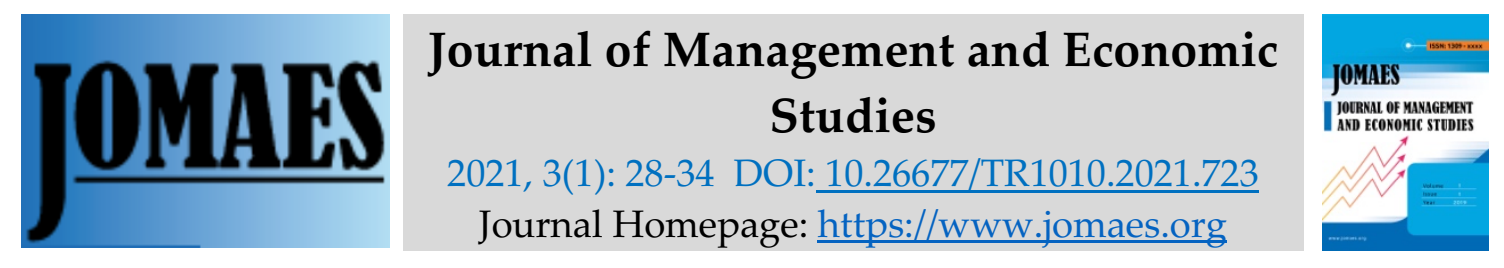

\title{
A Conceptual Overview of E-Sports Tourism as a New Trend in the Tourism Industry
}

\author{
Altan ÇETİN \\ Anadolu University, Tourism Management, Turkey. \\ altanc@anadolu.edu.tr, www.orcid.org/0000-0002-4271-4760
}

\author{
Mustafa COŞKUNER \\ Anadolu University, Tourism Management, Turkey \\ mustafacoskuner@anadolu.edu.tr, www.orcid.org/0000-0003-3032-1836
}

\begin{abstract}
The tourism industry is in a relationship with the sports discipline as well as with many other disciplines. Sports have been an important source of motivation for people to participate in tourism movements throughout history. As a result of the development of the internet and the developments in the digital age, the concept of traditional sports has also been affected by this development and the concept of e-Sports (electronic sports), which has been frequently encountered in recent years, has come into our lives. Events including e-Sports matches are watched worldwide today and reach large audiences. The mobility created by the participants from both domestic and abroad to these events also develops the tourism sector by contributing mainly to accommodation, catering, travel and transportation services. This dynamism in the eSports market and activities creates a supply source for alternative tourism potential in terms of the tourism industry, and e-Sports tourism is considered to be important in terms of product diversity. The purpose of this article is to examine and introduce the concept of e-Sports, which we come across recently, as a new tourism trend, by technology and computer, which are the outputs of the 21st century.
\end{abstract}

Keywords: Tourism, e-Sports, e-Sports tourism

\section{Introduction}

Tourism and sports are two of the important industries associated with more than one sector. Sports events are an important element of the marketing mix for tourist destinations. Sportsbased tourist travel and vacation form the basis of sports tourism. In previous years, sports were considered as an element that supports the product in tourism, but today it is the main starting point of touristic visits. There are two types of tourists participating in sports tourism. The first of these is sports participation travels (those who travel to participate in sports, recreation, leisure 
activities) and the second is sports audience travel (those who travel for the purpose of watching sports, recreation, leisure activities) (Bayram, 2018:18). Today, technological developments have shown a rapid change and development, resulting in the emergence of some new developments in the field of sports as in every field. One of these developments in the field of sports is electronic sports made online via computers. E-sports activities and events have taken their place as one of the attractions of the tourism industry as well as actors, viewers, event organizers, sponsors and producers, with a large income and promotional potential.

Similar to touristic participation for any sports organization, esports events come to the fore as a tourism product and a tourist attraction. Considering the increasing number of e-Sports organizations with international participation, which are organized more and more widely around the world, the tourism potential of e-Sports activities can be better understood. National or international e-Sports tournaments are often held for a few days. Teams, players, coaches, other staff, etc. to the places where the tournaments take place. participates together. Considering that there are many teams participating in tournaments, these teams contribute significantly to tourism for the destination where the organization takes place. During the tournament, e-Sports fans also travel to the places where the tournament will be held in order to support their players or teams (Aktuna and Ünlüönen, 2017:7). Therefore, it is seen that e-Sports activities are in cooperation with tourism by creating a touristic activity source for both players and viewers. In line with these developments, e-Sports activities were examined as a tourism product in this study and e-Sports tourism was handled with its conceptual dimensions.

\section{E-SPORT}

Sports today have become an integral part of the global entertainment industry by modernizing as time has passed. While technology has helped the development of sport, it has also enabled the addition of new branches to sports. With the development of internet and computer hardware technologies, a new concept related to sports, e-Sports has emerged (Kartal, 2020:48). Electronic sports also have uses in the form of esports, eSports and e-Sports. E-sports category; it includes games played on platforms such as computers, consoles and smartphones. (Kocaömer, 2018:6). Thanks to the developing technology industry, people have become a part of technology. The technology industry, on the other hand, is making the necessary breakthroughs and making various arrangements in a way that people can play an interactive role. This industry that has developed itself has caused the disappearance of stereotypes and traditional lines (Evren et al. 2019:1424). The most important element that distinguishes the concept of e-Sports from the traditional concept of sports is that it is played online or offline through an electronic device in a completely digital space. In addition, e-Sports does not require large financial resources in terms of facilities/equipment compared to traditional sports. It is a new generation sport preffered by young masses with its ability to perform this sport in every region of the world and its competitive features invidually or as a team. It shows similar features as well as differences between traditional sports and e-Sports. Fans, players, coaches, clubs, tournaments, leagues, brands and sponsorships that exist in traditional sports also take place in e-Sports. Games, which are the products of the transition to the digital society, have shifted to the virtual and revealed the phenomenon of e-Sports (Kocaömer, 2018:25).

Whether e-Sports is a sport in the world with the view that it does not involve a physical activity is still a controversial issue. However, contrary to these views, e-Sports players use their reflexes, brain functions and hand-eye coordination during the game (Witkowski 2012: 359). In addition, e-Sports has been accepted as physical activity because it usually involves moving fingers on a keyboard and using a mouse (Filchenko, 2018: 3). Sport is not only about physical strength, but also includes showing a good performance (Argan, 2004:162). 
Recently, various definitions have been made about e-Sports, whose popularity has increased day by day and has managed to attract the attention of many people in the industrial and academic field. According to Argan et al. (2006), electronic sports is a sport in which two people from one side of the world to the other can meet and play games via the internet or people from all over the world, both physically and mentally, is a sport that encompasses much more than most sports require. The e-Sports Association of the South Korean country, which is defined as the capital of e-Sports, defined e-Sports as "recreational activity that includes competition by using mental and physical abilities in a virtual online environment similar to reality" (Albayrak 2019:6). On the other hand, the International E-Sports Federation (IeSF), recognized by the Asian Olympic Council (OCA), defines e-Sports as " a competitive sport performed in a virtual environment in which physical and mental skills are used to create victory conditions with generally accepted rules " (www.ie-sf.org). E-sports also refers to the organization of competitions and championships in various game branches in electronic environment, individually and in groups. The difference of electronic sports from traditional sports matches is that the struggle takes place in an electronic and virtual environment instead of a physical environment (Hollist, 2015:826). According to Hamari and Sjöblom (2017), esports is a form of sports in which the primary aspects of the sport are facilitated by electronic systems and mediate both the inputs of the players and teams and the outputs of the e-Sports system with humancomputer interfaces. Although it is also called electronic game, cyber game, online game, the situation that is basically expressed is the sports activity carried out in electronic form. Although e-Sports is a newly emerging concept, it is an organized sport that has an increasing number of players and followers, as it includes many physical reflexes and different mental skills (Bayram, 2018: 19).

Another noteworthy issue about e-Sports is the generations or age groups of the participants. Unlike other generations who prefer to socialize via the internet, the participants of the group called Generation $\mathrm{Y}$ and the millennium or the generation $\mathrm{Z}$, which is called the internet generation, can use iPads, laptops, game consoles etc. instead of toys. It is a community that prefers digital tools and grows with technology. While this generation takes the place of the $X$ generation; It will be possible to say that the understanding of travel, leisure time and vacation has also changed today. It is seen that the e-Sports trend is a unique opportunity to catch the $\mathrm{Z}$ generation in terms of the tourism industry and to create tourism diversity as an alternative (Gül et al., 2017:107).

E-sports, which is considered to be included in the Olympic games by the International Olympic Committee (IOC) and is expected to be accepted as a medal sport in Asia 2024, is growing day by day (Albayrak, 2019:6). Thanks to the games that attract the attention of millions of people, the communication, sports and technology industries are indirectly new partnerships they have established, purchases from many different fields and the e-Sports industry strengthens and develops every year. However, due to the Covid-19 pandemic, which deeply affects all humanity and many industries in the world, global e-Sports revenues, which are expected to be 1.1 billion dollars in 2020, remained at the level of 950.3 million dollars. Despite this, e-Sports revenues are expected to increase by $15 \%$ until 2023 , to reach 1.6 billion dollars. In addition, the total number of viewers of 443 million in 2019 increased by $11.7 \%$ in 2020, reaching 495 million viewers. The total number of viewers estimated for 2023 is 646 million (Newzoo 2020 Global Esports Market Report).

E-sports under the Federation first Turkey Emerging Sports Sector in Turkey " digital game " as a sport by the name TC was part of the Youth and Sports Ministry of Finance but due to Sports General Directorate with the approval of the ministry in 2018 in this sport federations Turkey converted into e-Sports Federation (TESFED) Presidency was established (the 
www.tesfed.gov.tr). The number of smartphone users in our country has exceeded 40 million. The number of people playing on the phone at least once a day increased to $65 \%$ in 2020 . The number of e-Sports players has also increased by 30\% compared to 2019 (www.gamefactory.gs). Also spend 58 minutes a day using the game console users in Turkey (www.wearesocial.com). In 2020 , mobile game revenues constitute $49 \%$ of the global market. The total revenue from digital games in our country is $\$ 878.8$ million, and the number of players and fans in the e-Sports ecosystem is at least 7 million. Turkey also ranks 18th in the world in the digital games market (T. C Youth and Sports Ministry of e-Sports Report, 2018). In Turkey, Galatasaray, Besiktas and Fenerbahce sports club created their own electronic sports team. These sports clubs, which started to operate in the field of electronic sports, even started to transfer players from abroad. This situation once again shows how serious electronic sports are (Aktuna and Ünlüönen, 2017: 6).

\section{E-SPORT TOURISM}

The phenomenon of sports tourism can be characterized as the intersection of sports marketing and tourism marketing. People who travel to attend or watch a sports event are considered as sports tourists. The reason for this is that the place where sports organizations will take place has a "travel" result (Argan, 2004: 162). In the light of this information, e-Sports tourism; It is possible to define it as a type of tourism based on the realization of electronic sports activities in a designated country and destination in the form of tournaments, participation of players, viewers, relevant institutions and organizations in these tournaments, use of various touristic activities such as eating, drinking, accommodation and entertainment (Bayram, 2018: 20) .

Sports tourism, as one of the alternative tourism types, is included in the tourism literature as a reflection of thousands of sports organizations (Olympic games, World Cup etc.) organized every year in the world. However, there are very few scientific studies examining the relationship between tourism and e-Sports in our country. Aktuna and Ünlüönen (2017) revealed the potential of e-Sports tourism, which they discussed under the title of sports tourism, in terms of product diversity in their research. Within the scope of Bayram (2018) planned behavior theory, a study was carried out on how effective behavioral attitude and control are on the travel intentions of participants in e-Sports activities. Yenişehirli et al. (2018), on the other hand, considered e-Sports activities as alternative tourism products and conducted a research on the tourism potential of eSports by associating these activities with the tourism paradigm. Dilek (2019) discussed the relationship between these two sectors by examining e-Sports activities within the tourism paradigm as a growing market.

E-sports has started to be seen as a new travel motivation for the tourism industry today. In addition, e-Sports is considered within the scope of special interest tourism as an important recreational activity (Yenişehirli et al., 2018: 342). One of the best examples in this context is eSports festivals. Hosted by England, the Insomnia and EPIC 23 festivals are festivals that last a few days with the participation of many audiences from different parts of the world. These festivals include many touristic services such as accommodation services, restaurants, after-game entertainment programs and musical shows (Bayram, 2018: 21). It clearly shows how strong the relationship of e-Sports, which includes similar touristic activities, with tourism is.

There are many reasons why e-Sports events are attractive. Viewers get the chance to watch the world's best e-Sports players contest and meet their favorite players and share their passions. For this reason, fans are eager to travel for miles to attend big events and watch the games on site (Dilek, 2019:14). E-sports tourists (especially the Z generation) come together at the destinations where the tournaments take place and experience a unique and unforgettable experience. This trend has created e-Sports tourism, which is considered a new type of tourism. As a growing 
market day by day, e-Sports activities constitute an important center of attraction for the tourism industry (Sarığlan and Bağlama, 2020: 244).

It stands out as a very suitable alternative in terms of making the name of the city where e-Sports tournaments are held known and attracting tourists to that region. E-sports organizations also benefit from the promotion and image of the countries and regions where the tournaments take place as the main motivation factor, as in the traditional Olympic games or the conduct of tourism activities for a football organization. Countries and destinations that offer e-Sports environments by fulfilling the organization requirements with high-cost investments stand out in terms of competition in meeting the demands of e-Sports tourists. Accordingly, creating a good e-Sports environment for players and viewers, gaining a certain advantage in competition for the image of the destination where the events take place, and maintaining the continuity of their demands is an issue that should be considered important by countries (Çetin and Kozak, 2019: 966). Esports provides great inputs to the economies of developed countries in terms of tourism, strengthens their existing image and is seen as a significant promotion tool. It is possible to say that some e-Sports tournaments such as FIFA World Cup and SuperBowl have economic benefits to the region with millions of participants on the internet, as well as promoting the culture of the region, increasing repeat visits, and helping to branding the destination (Bayram, 2018: 21).

\section{CONCLUSION AND RECOMMENDATIONS}

The increasing speed of technology day by day is the most important factor that spreads the use of electronic devices and computers in daily life. This situation has led to an increase in the demand for use of electronic-based activities. From the arcade to the game console and from the desktop computer to the interactive multiplayer network, this explosion of interest in digital games has been driven by access to the internet, which allows all activities such as downloading and updating software, making online payments, or finding and interacting with other players online. This intense interest in digital games has enabled an e-Sports industry to compete with other sectors (music, cinema, entertainment) and even exceed the revenues of other sectors.

One of the important ways for the development of the tourism industry is the creation and development of alternative tourism movements and tourism products. E-sports formation should also be considered as a tourism product. In this context, e-Sports tourism includes data that support this understanding with its economic inputs and direct and indirect contributions to tourism in the world in recent years. E-sports is taking firm steps towards becoming a truly viable and profitable market as a niche tourism attraction center (Dilek, as cited in Agius 2015, 2019:14).

E-sports tourism is important in terms of differentiation of the tourist profile, which is mostly similar for our country. In order to attract e-Sports tourists to our country, international organizations, which are examples in the world, can be organized with the sponsorship support of giant companies run at ministerial level in our big cities (especially İstanbul, Ankara, Izmir, Antalya, etc.). These organizations can provide a competitive advantage against countries competing in tourism in terms of country promotion and image. In addition, if e-Sports tourists benefit from accommodation, travel, food and beverage and transportation services in the cities and regions where the organizations they participate in, tourism income can be provided directly to the country.

The e-Sports trend, which has already developed in the world and continues to develop rapidly, has started to gain popularity in our country in recent years. Therefore, in the academic field, there are almost no studies in which e-Sports and tourism are handled and analyzed together. This study discusses this new tourism trend, which has recently become a subject in the literature, in a conceptual manner. However, it is predicted that tourism studies to be carried out with eSports participants for the development of e-Sports tourism will provide more detailed data 
about this concept. It is thought that this study will guide the researches about e-Sports and tourism.

\section{REFERENCES}

Albayrak, M. (2019). Elektronik Spor Tüketicilerinin Satın Alma Davranışlarını Etkileyen Faktörlere İlişkin Bir Araştırma, Sağlık Bilimleri Enstitüsü Antrenörlük Eğitimi Anabilim Dalı, Yüksek Lisans Tezi. İstanbul Gelişim Üniversitesi, İstanbul.

Aktuna, H. C., Ünlüönen, K. (2017). Yeni Bir Turizm Çeşidi Olarak Elektronik Spor Turizmi. Gazi Üniversitesi Turizm Fakültesi Dergisi, (2), 1-15.

Argan, M. (2004). Spor ve Turizm Pazarlamasının Kesişim Noktası Olarak Spor Turizmine Kuramsal Bir Bakış, Anatolia Turizm Araştırmaları Dergisi, 15(2): 158-168.

Argan, M., Özer, A. ve Akın, A. (2006). Elektronik Spor: Türkiye'deki Siber Sporcuların Tutum ve Davranışları. Spor Yönetimi ve Bilgi Teknolojileri Dergisi. 1 (2), 1-11

Bayram, A. T. (2018). Planlanmış Davranış Teorisi Çerçevesinde E-spor Turizmine Katılma Niyeti, Turizm Akademik Dergisi, 5(2): 17-31.

Çetin, A. ve Kozak, R. (2019). Fuar Katılımcılarının Destinasyon İmajı Algıları: Expo 2016 Antalya Örneği, Türk Turizm Araştırmaları Dergisi, 3(4): 964-976.

Dilek S. E. (2019). E-Sport Events Within Tourism Paradigm: A Conceptual Discussion, International Journal of Contemporary Tourism Research, 3(1): 12-22.

Evren, T., Kargün, M., Pala, A. ve Yazarer, İ. (2019). Spora Yenilikçi Yaklaşım, Uluslararası Sosyal Araştırmalar Dergisi, 12(66): 1424-1433.

Filchenko, M. (2018). A Comparison Between Esports and Traditional, San Jose State University Journal, 5(1): 1-10.

Gül, İ., Kızılırmak, İ., Güler, E. ve Yardı, Z. (2017). Fuar Turizmi Kapsamında Oyun Fuarları: Gaming İstanbul Örneği, Gazi Üniversitesi Turizm Fakültesi Dergisi, 2:101-120.

Hamari, J. and Sjöblom, M. (2017). What is eSports and Why Do People Watch It?, Internet Research, 27(2): 211-232.

Hollist K. E. (2015). Time to be Grown-ups About Video Gaming: The Rising Esports Industry and The Need for Regulation, Arizona Law Review, 57(3): 823-842.

Kartal, M. (2020). Küreselleşme Bağlamında Türkiye'de E-spor, Sağlık Bilimleri Enstitüsü Beden Eğitimi ve Spor Anabilim Dalı, Doktora Tezi. İnönü Üniversitesi, Malatya.

Kocaömer, C. (2018). Elektronik Spor Faaliyetlerinde Sponsorluğun Marka Değeri Üzerine Etkisi: League of Legends Örneği, Sosyal Bilimler Enstitüsü Halkla İlişkiler ve Tanıtım Anabilim Dalı, Yüksek Lisans Tezi. Ege Üniversitesi, İzmir.

Newzoo, (2020). 2020 Global Esports Market Report (Free Version), 1-31.

Sarıoğlan, M. and Bağlama, S. H. (2020). Critical Studies in Social Sciences and Humanities, Livre de Lyon, Lyon. France. 231-246.

T.C Gençlik ve Spor Bakanlığı E-Spor Raporu (2018). Eğitim, Kültür ve Araştırma Genel Müdürlüğü, Gençlik Araştırmaları Haber Bülteni, 5: 1-71.

Witkowski, E. (2012). On the Digital playing Field: How we "Do Sport" With Networked Computer Games, Games and Culture, 7(5), 349-374. 
Yenişehirli, E., Erdoğan, Ç., Şahin, S.; and Ulama, Ş. (2018). A Conceptional Research on Determining The Tourism Potential of Electronic Sports Events: Esports Tourism, Kesit Akademi Dergisi, 4(16): 341-353.

https://gamefactory.gs/turkiye-oyun-sektoru-2020-raporu/ [Retrieved on: 20.02.2021]

https://ie-sf.org/esports [Retrieved on: 20.02.2021]

http://tesfed.gov.tr/Sayfalar/3073/3072/hakkimizda.aspx [Retrieved on: 20.02.2021]

https://wearesocial.com/digital-2020 [Retrieved on: 28.02.2021] 